\title{
Debate
}

CONTROVERSY

\section{An ethical market in human organs}

\author{
Charles A Erin, John Harris
}

W hile people's lives continue to be put at risk by the dearth of organs available for transplantation, we must give urgent consideration to any option that may make up the shortfall. A market in organs from living donors is one such option. The market should be ethically supportable, and have built into it, for example, safeguards against wrongful exploitation. This can be accomplished by establishing a single purchaser system within a confined marketplace.

Statistics can be dehumanising. The following numbers, however, have more impact than most: as of 24th November, during 2002 in the United Kingdom, 667 people have donated organs, 2055 people have received transplants, and 5615 people are still awaiting transplants. ${ }^{1}$ It is difficult to estimate how many people die prematurely for want of donor organs. "In the world as a whole there are an estimated 700000 patients on dialysis .... In India alone 100000 new patients present with kidney failure each year" ${ }^{22}$ (few if any of whom are on dialysis and only 3000 of whom will receive transplants). Almost "three million Americans suffer from congestive heart failure ... deaths related to this condition are estimated at 250000 each year . . . 27000 patients die annually from liver disease .... In Western Europe as a whole 40000 patients await a kidney but only ... 10000 kidneys" 2 become available. Nobody knows how many people fail to make it onto the waiting lists and so disappear from the statistics. It is clear that loss of life, due in large measure to shortage of donor organs, is a major crisis, and a major scandal.

At its annual meeting in 1999, the British Medical Association voted overwhelmingly in favour of the UK moving to a system of presumed consent for organ donation, ${ }^{3}$ a proposed change in policy that the UK government immediately rejected. ${ }^{4}$ What else might we do to increase the supply of donor organs? At its annual meeting in 2002, the American Medical Association voted to encourage studies to determine whether financial incentives could increase the supply of organs from cadavers. ${ }^{5}$ In 1998, the International Forum for Transplant Ethics concluded that trade in organs should be regulated rather than banned. ${ }^{6}$ In 1994, we made a proposal in which we outlined possibly the only circumstances in which a market in donor organs could be achieved ethically, in a way that minimises the dangers normally envisaged for such a scheme. ${ }^{7}$ Now may be an appropriate time to revisit the idea of a market in donor organs. ${ }^{8}$ Our focus then, as now, is organs obtained from the living since creating a market in cadaver organs is uneconomic and is more likely to reduce supply than increase it and the chief reason for considering sale of organs is to improve availability.

To meet legitimate ethical and regulatory concerns, any commercial scheme must have built into it safeguards against wrongful exploitation and show concern for the vulnerable, as well as taking into account considerations of justice and equity.

There is a lot of hypocrisy about the ethics of buying and selling organs and indeed other body products and services-for example, surrogacy and gametes. What it usually means is that everyone is paid but the donor. The surgeons and medical team are paid, the transplant coordinator does not go unremunerated, and the recipient receives an important benefit in kind. Only the unfortunate and heroic donor is supposed to put up with the insult of no reward, to add to the injury of the operation.

We would therefore propose a strictly regulated and highly ethical market in live donor organs and tissue. We should note that the risks of live donation are relatively low: "The approximate risks to the donor ... are a short term morbidity of $20 \%$ and mortality, of $0.03 \%$.... The long term risks of developing renal failure are less well documented but appear to be no greater than for the normal population." ${ }^{\prime 9}$ And recent evidence suggests that living donor organ transplantation has an excellent prognosis, better than cadaver organ transplantation..$^{10}$ Intuitively, the advantage also seems clear: the donor is very fit and healthy, while cadaver donors may well have been unfit and unhealthy, although this will not be true of many accident victims.

The bare bones of an ethical market would look like this: the market would be confined to a self governing geopolitical area such as a nation state or indeed the European Union. Only citizens resident within the union or state could sell into the system and they and their families would be equally eligible to receive organs. Thus organ vendors would know they were contributing to a system which would benefit them and their families and friends since their chances of receiving an organ in case of need would be increased by the existence of the market. (If this were not the case the main justification for the market would be defeated.) There would be only one purchaser, an agency like the National Health Service (NHS), which would buy all organs and distribute according to some fair conception of medical priority. There would be no direct sales or purchases, no exploitation of low income countries and their populations (no buying in Turkey or India to sell in Harley Street). The organs would be tested for HIV, etc, their provenance known, and there would be strict controls and penalties to prevent abuse

Prices would have to be high enough to attract people into the marketplace but dialysis, and other alternative care, does not come cheap. Sellers of organs would know they had saved a life and would be reasonably compensated for their 


\section{Debate}

risk, time, and altruism, which would be undiminished by sale. We do not after all regard medicine as any the less a caring profession because doctors are paid. So long as thousands continue to die for want of donor organs we must urgently consider and implement ways of increasing the supply. A market of the sort outlined above is surely one method worthy of active and urgent consideration.

\section{REFERENCES}

1 UK Transplant. http://www.uktransplant.org.uk/

2 Cooper DKC, Lanza RP. Xeno-the promise of transplanting animal organs into humans. New York: Oxford University Press, 2000: 7-17.

3 Beecham L. BMA wants presumed consent for organ donors. BM 1999;319:141.

4 Anon. Organ donor reform rejected. BBC News Online. 16 July 1999. http://news.bbc.co.uk/1/hi/health/ 396430.stm

5 Josefson D. AMA considers whether to pay for donation of organs. BM 2002;324:1541.

6 Radcliffe-Richards J, Daar AS, Guttman RD, et al. The case for allowing kidney sales. Lancet 1998:351:1950-2.

7 Erin CA, Harris J. A monopsonistic market-or how to buy and sell human organs, tissues and cells ethically. In: Robinson I, ed. Life and death under high technology medicine. Manchester: Manchester University Press in association with the Fulbright Commission, London, 1994:134-53. See also Harris J, Erin CA. An ethically defensible market in organs. BN 2002;325: 1 14-15.

8 Tuffs A. Debate fuels controversy over paid-for live organ donation. BM 2002;325:66; Hopkins Tanne J. International group reiterates stance against human organ trafficking. BM 2002;325:514.

9 Allen RDM, Lynch SV, Strong RW. The living organ donor. In: Chapman JR, Deierhoi M, Wight C, eds. Organ and tissue donation for transplantation. London: Arnold, 1997: 165 (original references omitted). See also-for example, Bay WH, Herbert LA. The living donor in kidney transplantation. Ann Intern Med 1987;106:719-27; Spital A. Life insurance for kidney donors - an update. Transplantation 1988;45:819-20. In this last study it was reported that in a sample of American life insurance companies, all would insure a transplant donor who was otherwise healthy and only $6 \%$ of companies would load the premium. We are indebted to Søren Holm for pointing us to these latter two sources.

10 Hariharan S, Johnson $C P$, Bresnahan BA, et al. Improved graft survival after renal transplantation in the United States, 1988 to 1996. N Engl J Med 2000:342:605-12. See also Gjertson DW, Cecka, M. Living unrelated kidney transplantation. Kidney International 2000:58:491-9; Terasaki PI, Cecka JM, Gjertson DW, et al. High survival rates of kidney transplants from spousal and living unrelated donors. N Engl J Med 1995;333:333-6. We are indebted to Aaron Spital for pointing us to these sources.

\section{CONTROVERSY}

\section{Is the sale of body parts wrong?}

\section{J Savulescu}

J Savulescu, Oxford Centre for Applied Ethics, University of Oxford, Suite 7, Littlegate House, St Ebbes Street, Oxford OXI 1PT, UK;

ime@bmigroup.com

Accepted 4 October 2002 n late August 2002, a general practitioner (GP) in London, Dr Bhagat Singh Makkar, 62, was struck off the medical register after he was discovered to have bragged to an undercover journalist about being able to obtain a kidney from a live donor in exchange for a fee. He told the journalist, who posed as the son of a patient with renal failure: "No problem, I can fix that for you. Do you want it done here, do you want it done in Germany or do you want it done in India?" The price he quoted included payment to the donor and "my administration costs". Dr Makkar said he regretted giving "stupid answers" to the journalist. He had been "tired, confused, and upset after a long day dealing with emotional patients".

Deliberation about ethics is often muddied by the personalities involved in a particular issue. Many people are uninspired by Richard Seed or Jack Kevorkian. This contaminates their view about the much broader and important issues such as cloning or euthanasia that Seed and Kevorkian, whom some people might describe as mavericks, have shoved their finger in.

Discussion of the sale of organs is overshadowed by cases of exploitation, murder, and corruption. But there is also a serious ethical issue about whether people should be allowed to sell parts of the body. It applies not only to organs, such as the kidney or parts of the liver, but also to tissues, such as bone marrow, gametes (eggs and sperm) and even genetic material. The usual argument in favour of allowing the sale of organs is that we need to increase supply. In the US, as few as $15 \%$ of people who need kidney transplants ever get a kidney. Cadaveric organs will never satisfy the growing demand for organs. Worldwide, hundreds of thousands, if not millions, die while waiting for a transplant.

Those opposed to a market in organs argue that markets reduce altruistic donation and may also threaten the quality of organ supply. They also claim it will exploit those who are forced by poverty to enter such a market.

Charles Erin and John Harris have proposed an "ethical market" in organs (p 000). The market would be confined to a self governing geopolitical area-for example, the UK or Australia. Vendors could sell into the system, from which their family members would stand a chance of benefiting. Only citizens from that area could sell and receive organs. There would be only one purchaser, an agency like the National Health Service (NHS) or Medicare, which would buy all organs and distribute according to some fair conception of medical priority. There would be no direct sales or purchases, no exploitation of low income countries and their populations. ${ }^{2}$

But there seems to me to be a much stronger argument in favour of sale of body parts. People have a right to make a decision to sell a body part. If we should be allowed to sell our labour, why not 
sell the means to that labour? If we should be allowed to risk damaging our body for pleasure (by smoking or skiing), why not for money which we will use to realise other goods in life? To ban a market in organs is, paradoxically, to constrain what people can do with their own lives.

Think about a couple with two young children who are contemplating buying a house. They find one for $\$ 150000$, but in a heavily polluted and unsafe area. They could spend another $\$ 50000$ and live in a cleaner, safer area. But they decide to save the money and expose their children to a greater risk in order to pay for private education.

Or consider the diver. He takes on a job as a deep sea diver which pays him an extra \$30 000 than he could otherwise earn. This loading is paid because the job has higher risks to his life and health. He takes the job because he likes holidays in expensive exotic locations. ${ }^{3}$

In both these cases, people take risks for money. They judge that the benefits for their own lives or their family's outweigh the risks. To prevent them making these decisions is to judge that they are unable to make a decision about what is best for their own lives. It is paternalism in its worst form.

There are two crucial issues. Firstly, we need to ensure that the risk involved is reasonable compared with the benefits it will offer to the person undertaking the risk and society. Secondly, people need to be fully informed and to give their consent freely. By "freely", I mean that they are not in a situation which is itself wrong or unacceptable. Poverty which is acceptable to a society should not be a circumstance which prevents a person taking on a risk or harm to escape that poverty. It is double injustice to say to a poor person: "You can't have what most other people have and we are not going to let you do what you want to have those things".

When people go to war voluntarily, risking their lives for their country, they are heralded as heroes. If we allow people to die for their country, it seems to me we should allow them to risk death or injury for the chance to improve the quality of their lives or their children's lives or for anything else they value. Money for these people is just a means to realise what they value in life. Whether or not a private market in organs will increase supply or improve its quality, it seems that people have a right to sell them.

\section{AUTHOR'S NOTE}

A version of this article was originally written for Australian Medicine. It appeared last year. Savulescu J. For sale ... body parts. Australian Medicine 2002;14:19.

\section{REFERENCES}

1 GP struck off for organ trading. The Guardian, accessed at http://society.guardian.co.uk/ nhsperformance/story/0,8150,783399,00.html on 25/9/02.

2 Erin CA, Harris J. An ethical market in organs J Med Ethics 2003;29:137-8.

3 Savulescu J. Taking the plunge. New Scientist $2001 ; 169: 50$.

\section{CONTROVERSY}

\section{Commentary. An ethical market in human organs}

\section{J Radcliffe Richards}

$\mathrm{T}$ his paper offers a positive suggestion for the management of a market in organs for transplant; and in doing so provides a useful opportunity for clarifying the structure of the Great Organ Sales Debate.

The issue is in constant need of clarification, because it is usually aired as a political question of the For and Against variety: should organ selling be legal or not? This format usually encourages protagonists to collect into an unsorted heap whatever arguments look as though they might have any persuasive force on their side, and because people may be on the same political side for different moral reasons, or have the same moral principles but reach different political conclusions, the political arguments tend to obscure both the real issues and the logical structure of the controversy.
Although attitudes to organ selling seem to have relaxed somewhat since the subject first came to light about a dozen years ago, most professional and political opinion is still against it. But what is the moral basis of this opposition? If you think organ selling should remain illegal, what exactly is your reason? Is it that you regard selling body parts as wrong in itself, irrespective of consequences? Or is it because you think that although it is not wrong in itself, in practice the harms will usually or always outweigh the benefits? Either of these quite different views might support the same political conclusion.

In practice, it is not clear that many opponents of organ selling have ever recognised the distinction. Most of the individual arguments are of a kind that implies the second view, because they are about anticipated harms of allowing the practice: coercion, exploitation, shoddy standards,
Debate

J Radcliffe Richards Centre for Bioethics and Philosophy of Medicine, Department of Medicine, University College London, Gower Street, London WCIE 6BT, UK;

i.rr@chime.ucl.ac.uk

Accepted 17 March 2003 


\section{Debate}

profiteering, misinformation, undermining altruism, deterring donation, and the like. But the overall structure of the debate makes it pretty clear that most opponents are totally against the buying and selling of organs on principle. One indication of this is the astonishing speed with which the practice was denounced and prohibited when it first came to light. There was no agonised weighing of pros and cons, as you would expect if what mattered was to balance good and bad effects; indeed the rather striking prima facie benefits of allowing the sales-saving lives, and allowing would be vendors to decide for themselves about their own best interests-were not even mentioned. Another indication that most opposition is rooted in the idea that organ selling is simply wrong in itself is the fact that whenever an argument on the Against side is demolished, others immediately appear to take its place. If the vanquished argument were the real basis of the objection, the objection should disappear. Since it does not, it is clear that most opponents have objections other than the ones they offer

To the practically minded it may seem that moral division-or confusion-among the politically united does not matter much. But in fact the division between these two kinds of reason for objecting to organ sales is much more significant than the all-things-considered political conclusion. It is of crucial importance to the conduct of the debate. If you regard organ selling as wrong in itself you may well embrace all suggestions of dangers and difficulties with relief, because they seem to strengthen the political case for prohibition. But if you start with the idea that what matters is to weigh harms and benefits, and that there is a prima facie case for allowing transactions that can save the life of purchasers and give vendors something they value more than their kidney, you will look at the objections raised in quite a different way.

In the first place you will look at them critically, rather than rushing to accept them-and will soon find that a good many have no force at all, because they involve logical fallacies or invented facts. ${ }^{1}$ And then, when you find real dangers and difficulties, you will try to devise techniques for avoiding the harm while keeping the good. This is, after all, what we automatically do in other contexts. The existence of rogue builders and medical quacks does not lead us to try to stop building or medicine altogether: obviously, we aim for controls that will minimise the bad but keep the good. (When possible dangers of organ selling are treated as objections to the whole idea, rather than as problems to be overcome if possible, that is further evidence that they are not the real objection.)

It is in this context that the Erin and Harris proposal should be understood. The authors recognise that there is a prima facie case for allowing organ sales, but they also recognise that a totally free market could do a great deal of harm. What they propose, therefore, is a restricted market, designed to allow the benefits while preventing these harms.

So how good a proposal is it? Once you get beyond the idea that organ selling is wrong in itself, you are into the terrain of highly complex empirical questions, and there is no point in philosophers's (or anyone's) engaging in armchair speculation about them. Recognition of how this proposal fits into the debate as a whole does suggest, however, the kinds of question that should be raised about it.

If it is presumptively bad to prevent sales altogether, because lives will be lost and adults deprived of an option some would choose if they could, it is for the same reason presumptively bad to restrict the selling of organs. Once you recognise that the default presumption is in favour of any such transaction, you should be reluctant to prevent any more sales than necessary. The Erin and Harris proposal, if viewed as representing the only circumstances in which buying and selling should be allowed, is restrictive in many ways. Is there good enough reason for ruling out the many potential sales it would prevent? Here are one or two questions about it

For instance, the idea of achieving equity of distribution by limiting purchases to public bodies, is obviously attractive. But in countries where there is no such service, or where it is generally accepted (as here) that people who find the public service inadequate to their needs should be allowed to go outside it, is there any justification for providing special restrictions on the freedom to make private arrangements to find a kidney? It would probably be best to have public bodies that supplied all needs-but until all needs are supplied in this way, is there any good reason to prevent (properly controlled) private arrangements?

And how good is the justification for keeping the market within a "self governing geopolitical area"? Of course there is something undesirable about a one way international traffic from poor to rich; but that is not enough to settle the all-things-considered question of whether it should be allowed. Much international trade is currently objectionable on the same grounds, but simply stopping it would be worse for the poor countries. It is much better, for them, to improve the conditions of trade than to prevent it altogether. Is the case different with organs?

These questions are not intended as rhetorical: they may have answers. Or even if they have not, perhaps the proposal is restricted to give it greater chance of political success. But the matter does need to be checked. It is clear that strong feelings against organ selling colour every aspect of the debate, giving apparent weight to arguments whose inadequacy nobody could miss in neutral circumstances. Could such feelings be influencing even this proposal, making it more restrictive than it should be? Whatever the answer, it is morally essential to ask the question.

\section{REFERENCE}

1 Radcliffe Richards J. Nephrarious goings on: kidney sales and moral arguments. J Med Philos 1996;21:375-416. (For a detailed account of the familiar arguments and their shortcomings.) $A$ summarised version also appears in Radcliffe Richards J, Daar AS, Guttman RD, et al, for the International Forum for Transplant Ethics. The case for allowing kidney sales. Lancet 1998;351:1950-2. 


\title{
Debat conrouvers Debate \\ Janet Radcliffe Richards on our modest proposal
}

\author{
Charles A Erin, John Harris
}

Charles A Erin

John Harris Institute of Medicine, Law and Bioethics, School of Law, University of Manchester Manchester M13 9PL, UK; John.M.Harris@man.ac.uk

Accepted 25 March 2003 $\int$ p anet Radcliffe Richards is as always to the point and radical. We agree with her that "if it is presumptively bad to prevent sales altogether because lives will be lost . . . it is for the same reason presumptively bad to restrict the selling of organs". Her complaint against our paper is that we are unnecessarily restrictive. John Harris indeed has argued that there are no sound ethical or philosophical reasons for objecting on principle to the sale of live tissue and organs. ${ }^{1}$ If a scheme can be devised which meets most of the objections standardly brought against organ sales, however, then even though it is more restrictive than alternatives and even if the objections that it meets are themselves unsound, it may have a great deal to recommend it. And of course the main thing it has to recommend it is that the sooner a consensus can be achieved for permitting sales (even on our highly regulated model) the sooner we begin saving more lives. If we keep our "eyes on the prize" we will advocate the scheme most likely to succeed even if a more radical scheme is theoretically justifiable.

Thus when Radcliffe Richards says: “Of course there is something undesirable about a one way international traffic from poor to rich; but that is not enough to settle the all things considered question of whether it should be allowed" she is again right. It is not enough to settle that question. Our paper was not trying to settle that question. ${ }^{2}$ We have proposed a scheme that would maximise organ sales by meeting the most common and persistent objections to commerce in body parts. In our paper we note that: "In 1994, we made a proposal in which we outlined possibly the only circumstances in which a market in donor organs could be achieved ethically, and in a way that minimises the dangers normally envisaged for such a scheme" and this is the proposal that we repeat in abbreviated form. The claim we make, which it seems Radcliffe Richards judges to be too strong, is that our proposal outlines "possibly the only circumstances in which a market in donor organs could be achieved ethically"; but note that there is a qualification to this claim, namely that if the first part of our claim is true it is so because it defends organ sales "in a way that minimises the dangers normally envisaged for such a scheme". It may be that organ sales could be defended (possibly by Janet Radcliffe Richards and for that matter by the present authors) in a way that does not minimise such dangers. But that is not what we were trying to do in our paper.

\section{REFERENCES}

1 Harris J. Wonderwoman and Superman. Oxford: Oxford University Press, 1992: ch 6.

2 Again this is something John Harris attempted in Wonderwoman and Superman. 